\title{
Capítulo 1 - Um menino, um jovem, um poeta, um pai, um observador da natureza no século XIX
}

\author{
Flavia Pacheco Alves de Souza
}

\section{SciELO Books / SciELO Livros / SciELO Libros}

SOUZA, F. P. A. Um menino, um jovem, um poeta, um pai, um observador da natureza no século XIX. In: Notas de um naturalista do sul do Brasil: Fritz Müller: história da ciência e contribuições para a biologia [online]. São Bernardo do Campo, SP: Editora UFABC, 2017, pp. 9-46. ISBN 978-85-68576-809. https://doi.org/10.7476/9788568576809.0003.

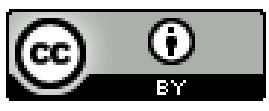

All the contents of this work, except where otherwise noted, is licensed under a Creative Commons Attribution 4.0 International license.

Todo o conteúdo deste trabalho, exceto quando houver ressalva, é publicado sob a licença Creative Commons Atribição 4.0.

Todo el contenido de esta obra, excepto donde se indique lo contrario, está bajo licencia de la licencia $\underline{\text { Creative }}$ Commons Reconocimento 4.0. 


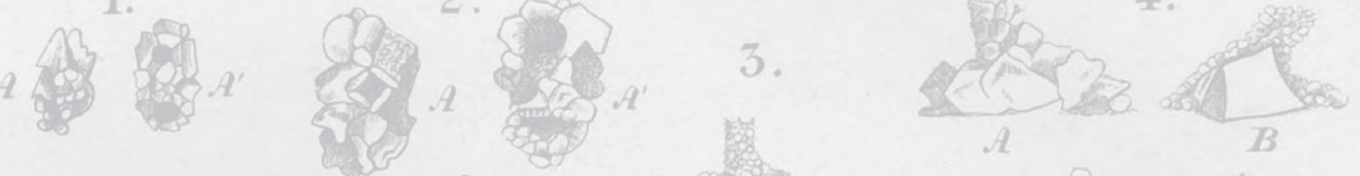

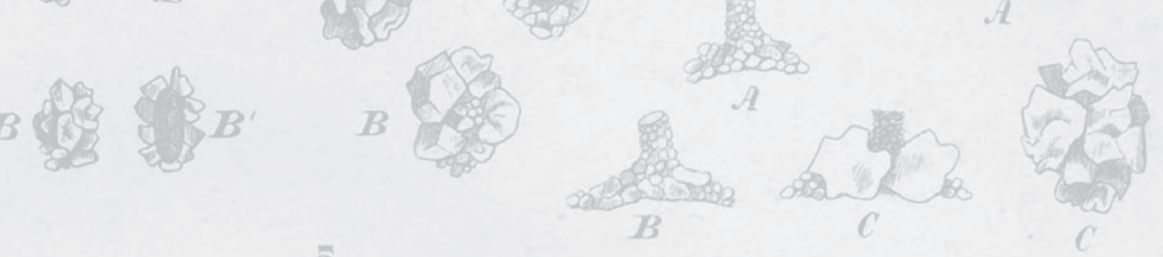

5.
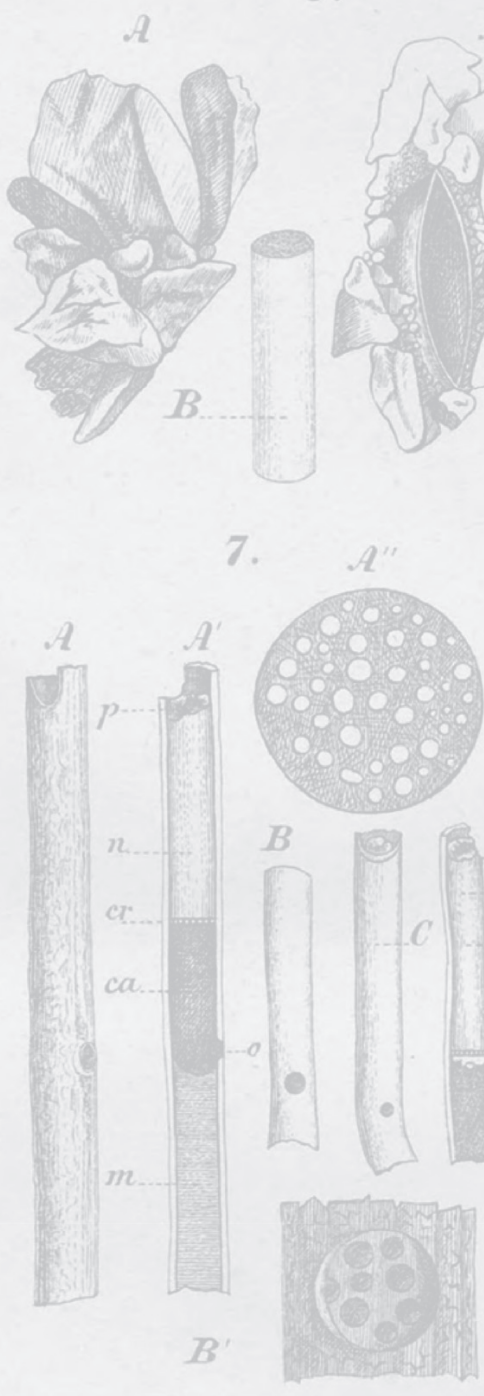

9.
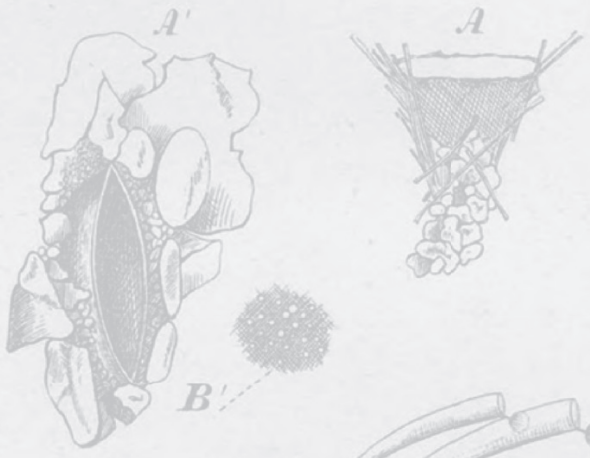

6.

B

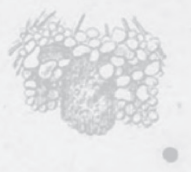

8.

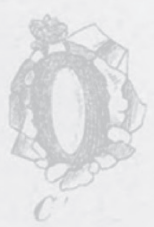




\section{UM MENINO, UM JOVEM, UM POETA, UM PAI, UM OBSERVADOR DA NATUREZA NO SÉCULO XIX}

\section{$1.1 \mathrm{O}$ jovem alemáo Fritz Müller}

D. Pedro de Alcântara, príncipe regente do Brasil, aceitou o pedido dos membros do Senado da Câmara do Rio de Janeiro e decidiu ficar no País, contrariando a Corte Portuguesa. O episódio ficou popularmente conhecido como o "Dia do Fico", de 1822. Meses mais tarde, no dia sete de setembro, o príncipe declarou a independência do Brasil em relaçáo a Portugal, proferida nas margens do Rio Ipiranga em Sáo Paulo. O levante ganhou o título de o "Dia do Grito".

A $9.432 \mathrm{~km}$ de distância do local da independência, percurso equivalente na época a dois meses de viagem em navio a vapor, nascia Johann Friedrich Theodor Müller, no dia 31 de março, na aldeia de Windischholzhausen, distrito de Erfurt, na Thüringen (Turíngia), Prússia. Hoje corresponde à regiáo central da Alemanha (Figura 1).

Neste ano, o distante Brasil, que seria futuramente sua pátria por 45 anos, rompia a condiçáo de estado de colônia de Portugal, iniciando seus primeiros passos à consolidaçáo do Império, posteriormente dissolvido em 1889. A Alemanha, por outro lado, já não mais pertencia ao Sacro Império Romano-Germânico desde 1806 e, com a tentativa em 1815 do Congresso de Viena em estabelecer a Confederação Germânica, era um conglomerado 
de 39 estados individuais, conhecido como Liga Alemã, em que os estados mais proeminentes eram a Prússia e a Áustria.

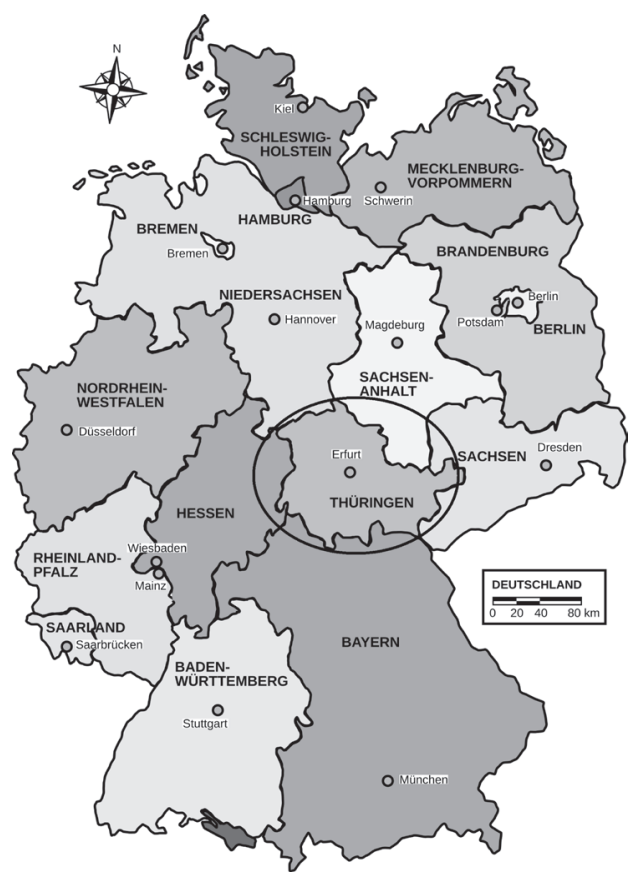

Figura 1 - Mapa atual da Alemanha. A área circulada corresponde ao Estado da Turíngia, local em que Müller nasceu.

Fonte: Wikimedia Commons (2014).

O menino receberia ao longo da vida diferentes nomes: no mundo científico se estabeleceu a forma abreviada, Fritz Müller; Fritz Müller-Desterro nos círculos científicos europeus ${ }^{2}$, e, por

2 Como o nome Fritz Müller era comum no círculo científico alemão da época, foi sugerido por Ernst Haeckel (1934-1919), zoólogo e seu correspondente, que Müller ficasse conhecido no círculo científico alemão como Fritz Müller-Desterro, capital da província de Santa Catarina. Tal associação de seu nome com "Desterro" nunca o agradou (CASTRO, 2007, p. 61). 
fim, a forma "abrasileirada" de Frederico Müller, como assinava alguns de seus artigos publicados no Museu Nacional. Notavelmente, um grande destaque em sua família, pois ele era o primogênito de seis irmãos: três homens e três mulheres.

Seu pai, Johann Friedrich Müller, era pastor luterano de uma paróquia pobre da Turíngia, profissão herdada do pai, que, além de pastor, também foi professor de um colégio em Erfurt. Sua mãe, Dorothea Trommsdorff, era filha do famoso farmacêutico Johann Bartholomäeus Trommsdorff (1770-1837), um dos primeiros a tornar a farmácia uma ciência experimental na Alemanha, diferenciando-a das atividades místicas, com poderes milagrosos. Tais poderes eram atribuídos aos farmacêuticos no período em questão, visto que as farmácias ou boticas também eram espaços de vendas de drogas curativas e de extratos vegetais misturados ao álcool. Dessa forma, os frequentadores destes espaços muitas vezes faziam dos balcóes uma espécie de "taberna", medicando-se no próprio estabelecimento com os extratos vegetais (DIAS, 2005).

Trommsdorff possuía sua farmácia em Erfurt chamada de Schwanapotheke (Farmácia do Cisne). Diferente das demais, a Farmácia do Cisne ficou conhecida como um espaço de debate entre estudiosos. E foi na farmácia do avô que o jovem Müller teve seu primeiro contato com naturalistas alemães como Alexander Humboldt (1769-1859) e também com o químico e farmacêutico Ernst Wilhelm Martius (1756-1849), pai de Carl Friedrich Philipp Martius (1794-1868). Estes estudiosos foram companhias assíduas nas rodas de discussão de Trommsdorff.

Müller cresceu passeando pelos campos e bosques de Erfurt, acompanhado ora por seu pai, ora por seu avô materno, e ambos ensinavam ao menino curiosidades da natureza. Mais tarde, ele escreveria ao irmão Hermann recordando a figura do 
pai: "Nós, irmãos, herdamos dele o amor pela natureza viva" (CASTRO, 2007, p. 22).

West (2016, p. 8) relata que o pai de Müller teve um papel primordial em encorajar os irmãos a observarem a natureza durante os longos passeios. Também construiu com a ajuda dos filhos, Fritz e Hermann, um herbário para cultivo e observação de plantas. De fato, o entusiasmo do pai pela natureza despertou $o$ interesse de ambos os filhos para as ciências naturais.

$\mathrm{Na}$ adolescência, Fritz vai residir temporariamente com o avô, em Erfurt, para cursar o ginasial. Neste período, chegou a fazer um curso de farmácia e foi aprendiz do ofício, demonstrando grande interesse pela botânica e pela observação da natureza, o que o levou a escolha do curso de Filosofia na Universidade de Berlim $^{3}$, matriculando-se prioritariamente nas disciplinas ofertadas de ciências naturais e de matemática.

Apesar de ter seguido o caminho das ciências naturais, também possuía grande interesse e facilidade com idiomas, chegando a comentar isso em uma carta datada de 1881 ao seu irmão Hermann. Segundo ele, se tivesse obtido apoio em Erfurt nas suas tentativas de aprender italiano, russo, árabe e sírio, provavelmente teria sido linguista em vez de naturalista (ZILLIG, 1997, p. 45). Esta facilidade de Müller com idiomas também é demonstrada com o português ${ }^{4}$, língua utilizada em suas aulas

\footnotetext{
${ }^{3}$ A Universidade de Berlim foi inaugurada em 1810 pelo educador Wilhelm Humboldt, irmão mais velho do naturalista Alexander Humboldt. A partir de 1828, ficou conhecida como Universidade de Friederich Wilhelm, homenageando o rei da Prússia, Friederich Wilhelm III. Em 1840, passou a denominar-se Universidade de Humboldt, em homenagem ao seu fundador.

${ }^{4}$ Quanto ao português, Müller comenta em carta com o irmão Hermann, assim que chega ao Brasil: "Nós não precisamos aprender a falar português aqui em Blumenau porque raramente temos contato com os brasileiros; se necessário, posso fazer-me entender com eles, visto que a linguagem é fácil, é uma espécie de latim com ossos quebrados" (WEST, 2003, p. 80).
} 
em Desterro, assim como nos artigos para o Museu Nacional. Além do português, foi exímio com o inglês, nunca falou o idioma, mas escrevia corretamente para se comunicar com outros naturalistas. $\mathrm{O}$ amigo Darwin, mais de uma vez, o elogiou em cartas, acerca da facilidade com que Müller se comunicava em inglês, destreza essa que ele não possuía com o alemão, língua natural do amigo.

Matriculado em 1841 na Universidade de Berlim, teve aulas com Johannes Peter Müller (1801-1858), conhecido filósofo natural do século XIX e que o orientou em suas pesquisas com sanguessugas ${ }^{5}$, também presenteando o estudante com seu primeiro microscópio, utilizado para observação dos ovos destes anelídeos. Müller apresenta, em 1844, sua dissertação na Universidade, somando 22 páginas, sob o título: Hirudinibus circa Berolinum hucusquis observatis (Sobre as sanguessugas dos arredores de Berlim), em latim, língua oficial para a produção de dissertações no período (Figura 2).

Em dezembro deste mesmo ano, é promovido pela Universidade a Doutor em Filosofia e, em 1845, torna-se professor ginasial do mesmo colégio em que havia estudado anos antes em Erfurt, lecionando disciplinas de álgebra e história natural. Neste período reside novamente na cidade, porém na casa do tio Hermann, que estava no comando da Farmácia do Cisne, desde a morte do avô, ocorrida em 1837.

\footnotetext{
5 As sanguessugas são vermes anelídeos da classe dos hirudíneos. Eram utilizadas até metade do século XX em tratamentos de sangria com humanos, pois muitas espécies são hematófagas (alimentam-se de sangue).
} 


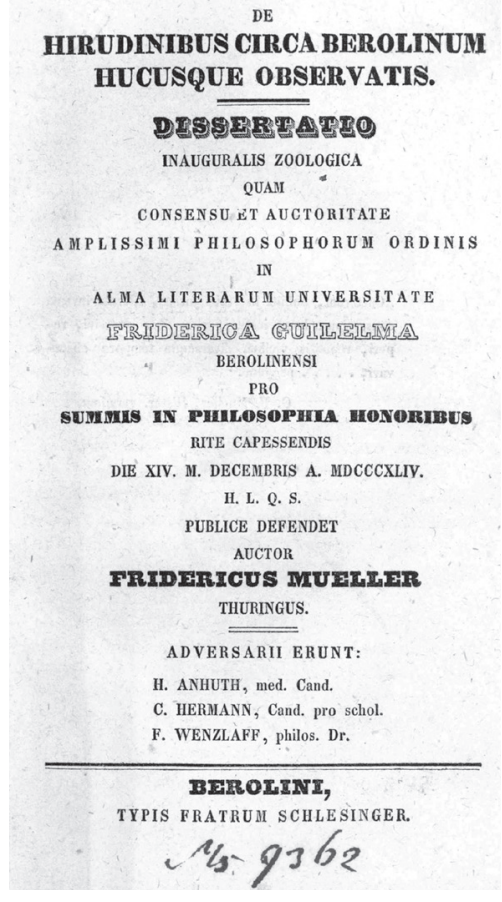

Figura 2 - Capa da dissertação de Müller apresentada à Universidade de Berlim, em 1844.

Fonte: Imagem gentilmente concedida pelo pesquisador Dr. Luiz Roberto Fontes.

Porém, a vida de professor ginasial não dura muito para ele, pois sonhava em viajar pelos trópicos, provavelmente influenciado pelas conversas presenciadas entre os diversos naturalistas, anos antes na farmácia do avô (Figura 3).

Com este objetivo, matricula-se na Universidade de Greifswald $^{6}$ para cursar Medicina, no ano de 1845. A escolha

\footnotetext{
${ }^{6}$ A Universidade de Greifswald foi fundada em 1456, com a aprovação do Sacro Império Romano-Germânico e do Papa da época. Localiza-se na cidade de Greifswald, na costa do Mar Báltico, local em que Müller iniciou suas pesquisas com crustáceos, grupo de invertebrados que estudou durante toda a vida.
} 
por Medicina devia-se ao fato de poder tornar-se médico de bordo em algum navio de expedição científica, o que lhe garantiria estabilidade financeira e, ao mesmo tempo, condiçóes e novos locais para suas pesquisas na natureza.

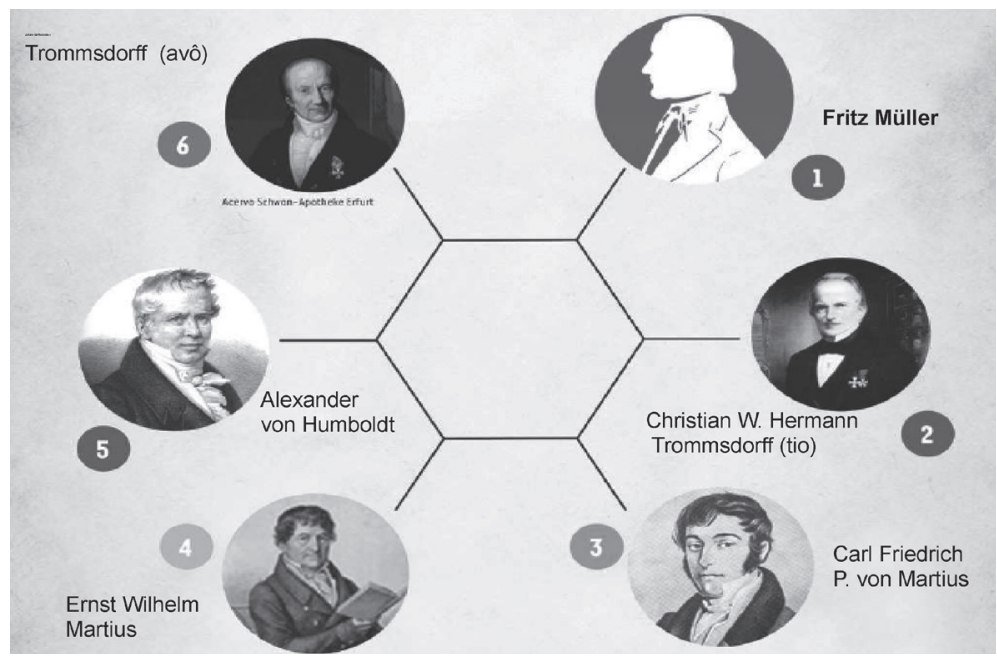

Figura 3 - Contatos e relaçóes na Farmácia do Cisne. Fonte: Fontes; Kupfer; Hagen (2012, p. 16).

No período do curso de Medicina em Greifswald, ele começou a participar de vários círculos liberais estudantis. Nas rodas de conversas se discutia religião e filosofia. Por meio dessas discussóes e leituras, ele se contrapôs à visão religiosa que recebeu em sua formação familiar, e passou a defender o direito de cada indivíduo à liberdade para seus assuntos pessoais que deveriam estar ligados à consciência (WEST, 2003, p. 33-53). Em cartas enviadas aos irmãos no período, confessa estes novos ideais. Um exemplo é a carta endereçada a August, na qual ele compartilha seu novo pensamento, que o guiaria pelo restante da vida: "assim como o corpo respira livremente, o espírito também deve respirar livremente". 
Em trecho de carta endereçada em 1846 à irmá Rosine, percebem-se mais detalhes sobre seu caráter e sua personalidade forte, o que o tornou um sujeito náo resignado aos assuntos científicos, políticos e religiosos de seu tempo:

É perfeitamente natural para a maioria das pessoas supor que, depois de olhar ao redor do mundo por um tempo, eu volte para meu lugar de origem e construa minha casa; porque eles, sem dúvida, ainda consideram a ambição e a curiosidade de aventuras minhas motivaçôes de vida. E me surpreende que você também espere isso de mim. Você sabe muito bem o laço que me une à minha terra natal (mesmo que, às vezes, ele me puxe para algum lugar distante). Eu disse a você, é claro, que eu devo cortar esse laço porque, dadas as minhas opinióes religiosas e políticas no clima atual, eu só poderia ter prosseguido minha carreira anterior como um hipócrita e escravo. Mas eu sei muito bem: esse laço será rompido para sempre! Eu náo preciso lhe dizer que é de melancolia dolorosa que esta certeza me preenche. E, no entanto, Rosie, há uma felicidade enorme em saber que sacrifiquei tudo pelas minhas próprias convicções (WEST, 2003, p. 34).

Müller participou ativamente de diversas organizaçôes estudantis com inspiraçôes socialistas, chegando a ser militante político do Partido Democrático, em 1848, ano em que diversos movimentos revolucionários tomaram conta do continente europeu, em parte pelo surgimento do proletariado industrial como força política (WEST, 2003, p. 37). Tais movimentos ficaram conhecidos como Revolução de 1848. Na Alemanha tomou duas vertentes antagônicas: uma que apoiava as reivindicaçóes independentistas dos Estados que formavam a Liga Alemã, e outra que apoiava a unificação destes em um só Império.

Esta mudança de perspectiva filosófica acerca das liberdades individuais e do papel da religião na sociedade - sintonizada 
com o contexto histórico vivido no século XIX em meio à construção da Alemanha como Estado moderno - foi essencial para o desenvolvimento de suas pesquisas científicas, já que não aceitou os fatos comumente estabelecidos como certezas inquestionáveis, criticando os pesquisadores de seu tempo. Conforme ele mesmo comenta em carta de 1846 ao seu irmão August, aqueles que adotavam nova postura religiosa e política na Alemanha sofriam perante o desconhecido e com o rompimento do vínculo que tinham desde a infância, conforme o excerto:

Três dos cinco médicos com quem estou associado, incluindo a mim, são racionalistas radicais, tanto na vida universitária quanto nos assuntos de religião. Tirar nossas conclusôes tem consequências inexoráveis e dolorosas, pois temos que desistir das ideias a que estamos agarrados com fervor desde a infância (WEST, 2003, p. 40).

A nova perspectiva de Müller, contrapondo-se à visão religiosa, tornou-se tão forte, que também foi a causa primária do não recebimento do diploma de médico, após ter concluído o curso de Medicina. Isto porque, na época, para a colação de grau e recebimento do diploma, o futuro médico deveria realizar um pronunciamento pedindo a ajuda de Deus na profissão: "Que Deus me ajude, com o santo evangelho"”. Apesar de Müller entrar com pedido antecipado na Universidade para realizar o juramento judaico (que não fazia menção aos evangelhos), este lhe foi negado, cabendo a ele se recusar a fazer o juramento cristão, ficando sem o diploma. Através dessa situação, é nítido observar sua personalidade forte, de quem prefere perder o diploma ao invés de obtê-lo traindo sua própria consciência.

7 Tradução livre da autora, a partir do latim: Sicut Deus me adjuvet et sacrosanctium ejus evangelium. 
Em 1848, conhece aquela que viria a ser sua companheira durante toda a vida: Karoline Töllner, filha de um lavrador pobre da cidade de Loitz. Um ano após conhecê-la, mesmo sem se casarem, nasce a primeira filha do casal, Louise.

Müller se referia, em cartas aos irmãos, à Karoline e à filha como "sua família", mesmo que Karoline fosse considerada ilegítima na Alemanha pela ausência legal do casamento. A união do casal só foi realizada em 1852, após o nascimento da segunda filha, Johanna Friederike Karoline e, pouco antes de emigrarem ao Brasil, por pressão de ambas as famílias.

Mas como Müller cede à pressão familiar aceitando o casamento? Zillig (1997) considera que este só ocorreu, não porque Müller tenha traído sua "consciência e seus novos ideais"; mas sim para evitar que a moça não emigrasse com ele ao Brasil e ficasse difamada perante os familiares alemães como concubina. É importante destacar como esse episódio pode representar, do ponto de vista histórico, uma parcela da dimensão das atitudes contestatórias e até revolucionárias que Müller tomava para conduzir seus assuntos pessoais, certamente com impactos em todas as outras dimensóes de sua vida, sobretudo no tipo de conhecimento que produziu ao longo de sua trajetória.

\subsection{Os primeiros anos na colônia de Blumenau}

Müller emigrou ao Brasil em 1852 acompanhado de sua esposa, sua segunda filha e seu irmão August ${ }^{8}$. Sua saída da Alemanha deveu-se, principalmente, à situação política e econômica vigente, sob a qual não conseguia tolerar.

\footnotetext{
8 A primeira filha de Müller com Karoline morreu com quase três anos de idade na Alemanha, em abril de 1852 . Na viagem ao Brasil, vieram com a segunda filha, Johanna, nascida em março de 1852.
} 
A fim de oferecer à sua família melhores condiçóes de vida, longe da Alemanha que contradizia seus ideais sociais, políticos e religiosos, Müller escolhe emigrar ao Brasil, devido ao conhecimento que possuía acerca da riqueza de fauna e de flora do País, adquirido anos antes na farmácia do avô, graças às conversas com os naturalistas frequentadores; e acrescido de leituras de contemporâneos, a exemplo do médico botânico Martius (1794-1868) e do zoólogo Spix (1781-1826), que produziram um relato de suas expediçôes ao Brasil, considerado no século XIX a maior fonte para conhecimento do País' (CASTRO, 2007).

O próprio Müller nos oferece três motivos por ter escolhido o Brasil:

Eu escolhi o Brasil, em primeiro lugar, por causa de sua rica flora e fauna, em segundo lugar porque pensei que aqui a índole alemã poderia se conversar mais facilmente do que entre os ianques, e em terceiro lugar, porque para mim os fundadores da colônia de Blumenau já me eram conhecidos de muitos anos (MÜLLER apud FONTES, 2009).

Müller conhecia o fundador de uma colônia alemã no Brasil, Hermann Bruno Otto Blumenau (1819-1899), que havia trabalhado na farmácia de seu avô e que, durante o ano de 1848 , instalou-se no Vale do Itajaí fundando uma colônia, a qual leva seu nome até a atualidade.

O Dr. Blumenau, como era conhecido, veio à primeira vez ao Brasil em 1846, visitando as colônias alemãs já instaladas

\footnotetext{
9 Além da obra de Martius e Spix, os livros do barão Wilhelm Ludwig Eschwege (1777-1855) eram muito conhecidos na Alemanha. Ele veio ao Brasil com a corte portuguesa em 1808, sendo nomeado superintendente das jazidas de ouro de Minas Gerais. Seus livros sobre as jazidas minerais brasileiras foram publicados na Alemanha e provavelmente foram responsáveis pela emigração de muitos alemães que sonharam em fazer fortuna nos trópicos.
} 
no Rio Grande do Sul e em Santa Catarina. Apresentou-se ao então imperador D. Pedro II com cartas de Alexander Humboldt e Carl Martius e, em 1848, negociou com o governador da província de Santa Catarina a compra de $220 \mathrm{~km}^{2}$ de terras na margem do Itajaí. Neste mesmo ano voltou à Alemanha com o objetivo de aliciar imigrantes para as "novas terras" e, em 1850, publicou um folheto de divulgação sobre as colônias brasileiras, amplamente divulgado na Alemanha (CASTRO, 1997).

Sob a direção do capitão Löfgren, no dia 19 de maio de 1852 , os irmãos Müller embarcaram no veleiro Florentin ${ }^{10}$ ancorado no porto de Hamburgo e fretado pela companhia colonizadora. A bordo estavam 232 emigrantes ${ }^{11}$ que chegaram à ilha de São Francisco, litoral de Santa Catarina, no dia 18 de julho de 1852. Devido à dificuldade de locomoção da época, os irmãos só chegaram à colônia de Blumenau (Figura 4) no dia 21 de agosto, três meses e dois dias após o embarque na Europa.

Nos primeiros dias, hospedaram-se na casa do fundador, o Dr. Blumenau. A colônia nesse período contava com 12 famílias. Os irmãos se instalaram em lotes às margens do Ribeirão Garcia, a uma hora da sua junção com o Itajaí ${ }^{12}$. Na época, era

10 Os emigrantes a bordo do Florentin ficaram conhecidos como Achtundvieriger (Grupo de 48), alusão aos emigrantes de uma Alemanha derrotada na Revolução de 1848. Disponível em: <http://www.arquivohistoricojoinville.com.br/ListaImigrantes/lista/6.htm>. Acesso em: 13 set. 2014.

11 Além dos 232 emigrantes, vieram 251 bebês. Houve 33 falecimentos a bordo do navio. Disponível em: <http://www.arquivohistoricojoinville.com.br/ListaImigrantes/lista/6.htm>. Acesso em: 13 set. 2014.

12 O local refere-se ao atual bairro Garcia, em Blumenau. De acordo com reportagem da Revista Blumenau em Cadernos (1958, p. 91), o nome "Ribeirão Garcia" não foi dado em homenagem a algum morador da região, que porventura tivesse este sobrenome. No século XIX, o Rio Camboriu, que banhava a região, já era conhecido como Rio do Garcia. Dessa forma, os moradores que habitavam estas imediações também ficaram conhecidos como "gente do Garcia". 
comum as distâncias entre locais serem medidas pelo tempo gasto de viagem, quer seja a pé ou por embarcação. Nesse sentido, a distância da casa dos irmãos Müller ao Rio Itajaí era de uma hora de embarcação.

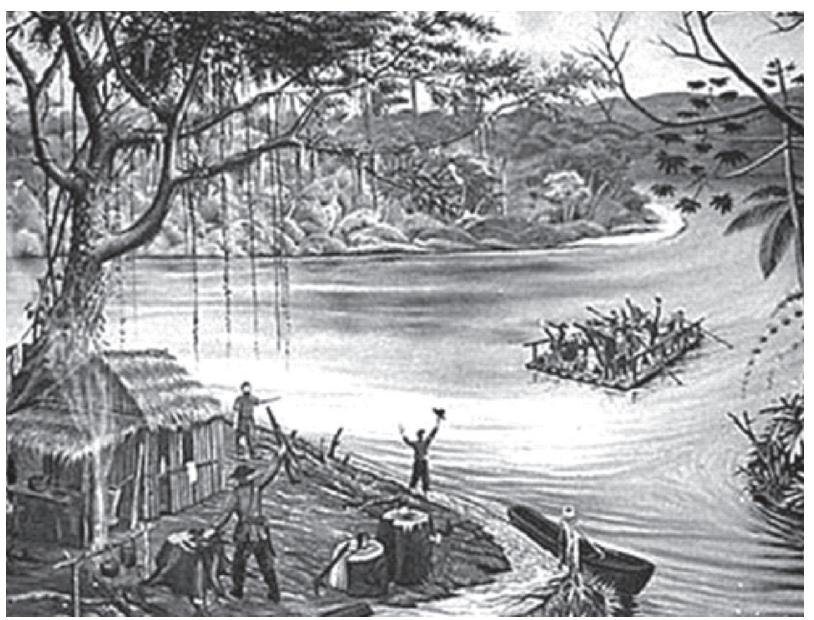

Figura 4 - Blumenau em meados de 1850, período de chegada dos irmáos Müller. Fonte: Acervo histórico de Blumenau.

Assim que ganharam os lotes, os irmãos logo iniciaram o trabalho braçal de limpar o terreno (derrubando as árvores da floresta) e construir as casas que os abrigariam na colônia. Apesar de Müller se queixar do trabalho braçal em carta à irmá Rosine, datada de 06 de janeiro de 1853, logo complementa que está muito satisfeito por ter chegado ao Brasil, mesmo diante das intempéries causadas pelo tempo, visto que no verão as temperaturas alcançavam $36^{\circ} \mathrm{C}$ e o concomitante tempo úmido mofava roupas e ferramentas.

Após a roçagem do terreno e a construção das casas, os irmãos também providenciaram uma área para o cultivo de vegetais 
e grãos utilizados na alimentação, visto que os produtos alimentícios eram muito caros e alguns somente chegavam à Província de Santa Catarina importados da colônia do Rio de Janeiro ou até mesmo da Europa. Um exemplo era o arroz branco e o açúcar refinado, o processo encarecia ainda mais o preço final do produto. Müller chega a enumerar para a irmã Rosine, em carta, os produtos vendidos em Blumenau, bem como os altos preços cobrados pelos comerciantes. De acordo com ele, os produtos diários para alimentação dos colonos baseavam-se em farinha de mandioca, feijão preto e carne seca; e nesta havia mais gordura do que carne. Além das dificuldades enfrentadas pelas intempéries e pela má alimentação, convém ressaltar que a região de Blumenau era habitada por etnias indígenas Kaigangs, Xoklengs e Botocudos, que aterrorizavam os colonos. Conforme pesquisa de Garrote (2012), os primeiros moradores da colônia, apoiados pelo Governo Imperial, consideravam o "índio", nome dado pelos colonizadores aos nativos da terra pertencentes a várias etnias diferentes, um entrave ao processo de colonização, um inimigo a ser vencido, assim como a floresta.

Müller comenta com a irmã um destes episódios, ocorrido às margens do Ribeirão da Velha ${ }^{13}$, a meia hora de sua residência:

Logo depois, estávamos muito excitados por outro incidente: (em 28 de dezembro) índios bugres, como os nativos são chamados aqui, fizeram um ataque surpresa em Blumenau às margens do Ribeirão da Velha, apenas a meia hora

13 A região ficou conhecida por Velha, cujo nome remonta a 1838, por existir uma senhora de idade bastante avançada, que morava às margens do ribeirão. Porém, há também a versão de que existia uma família de cognome Velha, antes da criação da Colônia Dr. Blumenau, e por esse motivo, o ribeirão ficou conhecido como Ribeirão da Velha em homenagem a esta família. Disponível em: http://www.blumenau. sc.gov.br/secretarias/secretaria-de-planejamento/pagina/historia-sobre-municipio/ divisa-administrativa-bairros/bairro-velha-seplan. Acesso 12 fev. 2015. 
daqui $[\ldots]$. Um dos moradores, Schramm, saiu de sua casa cerca de três horas da tarde e viu cinco homens morenos, nus, armados com arcos e flechas que se aproximavam de uma plantação de mandioca em uma colina nas proximidades; um sexto permaneceu no morro. Ele se aproximou dos índios, mostrou-lhes a arma e a depositou sobre seus pés, sinalizando que estava em uma abordagem pacífica e sem armas. Os índios pareceram entender o recado; porém através de uma ordem do líder do bando, que consistiu em um grito terrível e um bater de mão contra as coxas, eles iniciaram o ataque. Outro morador, Töpsel, ouvindo o barulho de Schramm, disparou sua arma em direção aos índios para assustá-los; eles pararam um momento, mas depois avançaram novamente. Schramm e Töpsel se dirigiram às casas e mandaram a esposa de Schramm com um companheiro para o Ribeirão Garcia, a fim de estarem seguros e buscar ajuda; os dois se esconderam em uma casa vizinha. Os índios se aproximaram da casa fazendo muito barulho (aparentemente para afastar e amedrontar quaisquer brancos restantes), dispararam várias flechas (com a mesma finalidade), e depois começaram a saquear. Foram levados sacos que se encontravam no jardim e alguns deles invadiram a casa de Blumenau (ele tinha ido para a Desterro) e Schramm podia ouvi-los remexer nos armários. Um dos índios, que estava prestes a também entrar na casa, olhou nervosamente ao redor e viu Schramm na janela da casa vizinha atirar; nesse momento ele foi baleado. Com um grito, ele jogou suas armas e fugiu dali acompanhado dos outros que saíram gritando (WEST, 2003, p. 73).

Outro fato interessante descrito neste primeiro ano na colônia foi a enchente que ele presenciou no Ribeirão Garcia. A inundação destruiu as áreas de cultivo e casas de muitos colonos, conforme trecho de correspondência disponível a seguir:

No final de outubro em meio ao tempo chuvoso, veio um dilúvio, como se não tivesse chovido por muitos anos. 
O Garcia ficou uns bons 20 pés ${ }^{14}$ acima do seu nível normal. Nenhum dano foi feito à minha propriedade, onde a terra sobe abruptamente a partir do rio. A maior parte da área que havíamos desmatado em agosto (roça, como eles chamam aqui) ficou debaixo de água, os galhos e troncos lamacentos já não queimavam, tudo ficou apagado em grande dor e despesa, já que todo o trabalho foi em vão. Para muitos dos colonos que vivem abaixo de nós, que construíram suas casas muito abaixo do nível, muitos viram suas casas ficarem completamente debaixo de água e muitas foram arruinadas. Além disso, a fome seguiu o dilúvio, visto que a cheia bloqueou as estradas e as canoas não podiam navegar rapidamente pelo Ribeirão Garcia” (WEST, 2003, p. 73).

Esta enchente do Ribeirão Garcia ocorre até os dias atuais, na área delimitada pelo sul da cidade de Blumenau, visto que o curso do ribeirão passa por vales úmidos com amplas áreas de várzeas e baixadas. Porém, difere dos primeiros tempos de colônia navegável, quando abastecia seus moradores com peixes. Atualmente ele é acometido por altos índices de poluição doméstica e industrial.

Apesar de a casa de Müller não ter sido acometida pela enchente, no final de setembro de 1880 , quando já residia às margens do rio Itajaí ${ }^{15}$, sua família precisou se afastar da casa por mais de uma semana devido à cheia do rio. Müller conseguiu retirar seus pertences a tempo, como seus livros e instrumentos, não sofrendo grandes perdas.

O episódio da "enchente de Blumenau de 1880" ficou tão conhecido no círculo científico europeu, devido à cidade ser a

\footnotetext{
14 Aproximadamente $6 \mathrm{~m}$ acima do nível, visto que a medida pé utilizada equivale a 0,3048 metros.

15 Em 1854, os irmãos venderam seus primeiros lotes e compraram outros, maiores. O museu ecológico Fritz Müller em Blumenau, está localizado onde era o lote de Fritz Müller (ZILLIG, 1997).
} 
residência de Müller, que Darwin recebeu esta notícia do botânico alemão Ernst Krause (1839-1903) e enviou imediatamente uma carta ao irmáo de Müller, Hermann, que residia na Alemanha, querendo saber quais foram as perdas de Fritz e se este ficaria ofendido se lhe propusesse o envio de dinheiro para reposição dos materiais perdidos, conforme o excerto de carta datada de 27 de novembro de 1880 :

Ele perdeu muitos dos seus livros, microscópio, instrumentos ou outros patrimônios? Se ele sofreu perdas dessa natureza, nada me daria maior prazer do que me ser permitido the enviar 50 ou 100 libras. O senhor acha que ele consentirá que eu aja assim? (ZILLIG, 1997, p. 217).

Cerca de dois meses após o envio desta carta, em 09 de janeiro de 1881, Müller escreveu a Darwin agradecendo a oferta e acalmando o amigo, visto que suas perdas não foram grandes:

Não sei como lhe expressar minha profunda gratidão pela generosa oferta que o senhor fez através de meu irmão ao ouvir da última e ameaçadora enchente do Itajaí. Do senhor, caro amigo, eu teria aceitado assistência sem hesitação se eu tivesse necessidade; mas felizmente, embora tivéssemos que abandonar nossa casa por mais de uma semana, e ao retornar achamos ela bastante avariada, minhas perdas não têm sido muito grandes (ZILLIG, 1997, p. 217).

Embora os moradores de Blumenau estivessem acostumados a enchentes periódicas do Itajaí e seus afluentes, pelo fato de a cidade estar em área de várzea, a enchente de 1880 ficou registrada na história do município, devido ao rio ter subido 14 metros acima do seu nível habitual. As ruas tornaram-se navegáveis, fazendo com que uma embarcação a vapor, o navio Progresso, auxiliasse no transporte das pessoas que estavam em situação de 
risco ou residiam afastadas do centro. Todas as estradas e pontes foram destruídas, as plantaçóes e estoques de alimentos foram perdidos, bem como as criaçôes de bovinos e suínos.

Soma-se às perdas materiais também a morte de muitos moradores, conforme o excerto do relatório de 09 de outubro de 1880, emitido pelo jornal local Kolonie Zeitung.

Os operários perderam suas casas e todos os instrumentos de trabalho. Quantos não salvaram apenas a vida, ao refugiarem-se no sótão de suas casas com seus pertences! Aconteceram particularidades que comovem o coração. É o caso de uma mãe com cinco filhos que se refugiou numa colina nas proximidades de sua casa. A colina ruiu soterrando-os, quando já se sentiam seguros. O pai da família, que trabalhava longe, no campo, ao regressar para casa, só o que ainda pôde fazer foi preparar a sepultura para a esposa e seus cinco filhos. Outra mulher, ainda jovem, era arrastada pelo turbilhão das águas, sob as vistas do marido. Adiante um homem, sem esperanças, não conseguia alcançar as máos que lhe eram estendidas e tragicamente desapareceu tragado pela correnteza do rio. Uma família teve que fugir às pressas, sem poder levar consigo uma só peça de roupa para agasalhar uma idosa avó e também a jovem mulher, por todos responsável, que dava à luz a oitava criança, nestas circunstancias de extrema penúria. Outra perdeu tudo, só lhe restando a casa vazia" (DAY, 2014 apud DEEKE, 1995).

Até mesmo a casa do fundador da colônia, Dr. Blumenau (Figura 5), também foi destruída por esta enchente, sobrando apenas a fotografia de como era sua residência antes desta ter ficado embaixo d'água.

Os relatos de Müller, encontrados em suas correspondências, podem ser considerados documentos históricos sobre os primeiros anos da colônia de Blumenau, visto que fornecem dados interessantes em relação à rotina na colônia, aos moradores, 
ataques indígenas, alimentação etc. Através destes relatos também pode-se perceber as mudanças significativas que ocorreram do século XIX aos dias atuais, principalmente as relacionadas à mudança da paisagem, causadas pelo desmatamento e urbanização, e à expulsão e/ou eliminação da população nativa, decorrentes após a colonização. A diversidade da flora era tão grande que Müller a descrevia continuamente ao irmão Hermann em cartas, informando-o também sobre os nomes das espécies encontradas, como o exemplo a seguir, de correspondência de 1853, sobre a flora do Vale do Itajaí:

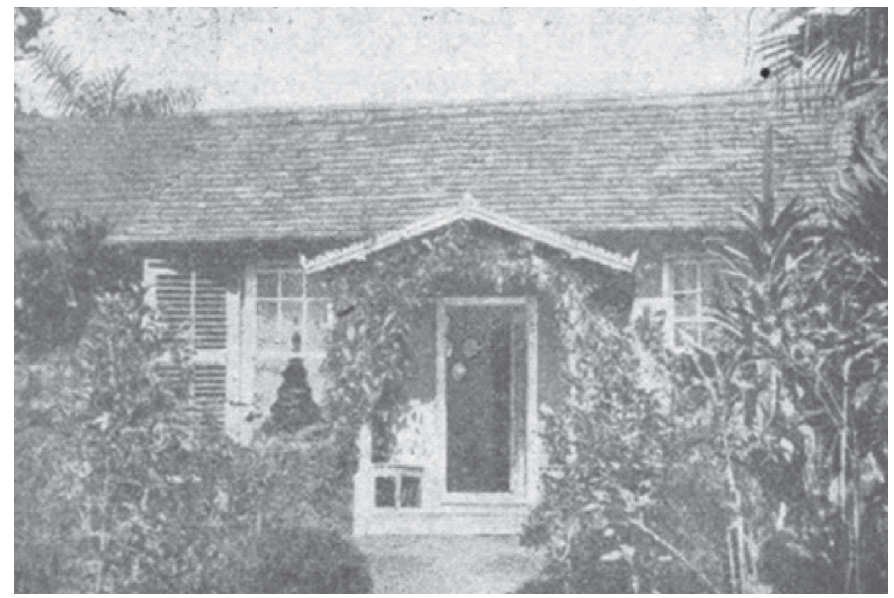

Figura 5 - Residência do Dr. Blumenau, destruída pela enchente de 1880. A casa localizava-se na Rua das Palmeiras, atual Avenida Duque de Caxias. Fonte: Acervo histórico de Blumenau.

$\mathrm{Na}$ floresta virgem há majestosas palmeiras imponentes, raízes aéreas de filodendros, bambus, e bromélias de folhas de cores vivas impressionantes que emergem sobre os troncos das árvores cujos ramos são pendurados com barba de velho (Tillandsia, também uma bromélia); no sub-bosque há tucuns (espinhosas palmeiras, Bactris setosa) uricanas (palmeiras de sombra, Geonoma pumila), helicônias da terra, palmeiras 
jovens, e por todo o lado inúmeros galhos podres caídos que conservam bromélias, aráceas e orquídeas. Nas margens do rio há cana brava (Pluma grama) e a flor ave do paraíso (Strelitzia); e em nossas plantaçóes, bananas, cana-de-açúcar e inhame. Estas plantas têm a maior influência sobre o caráter geral da nossa vegetaçáo (WEST, 2003, p. 87).

Quanto à população nativa, também foram grandes as transformações, e atualmente não existe em Blumenau nenhum local considerado como território indígena, revelando a dimensão do profundo impacto da política de colonização da regiáo, no século XIX, quanto à diminuição da diversidade étnica, populacional e ambiental.

\subsection{Os anos na capital da província, Nossa Senhora do Desterro}

O fundador da colônia, Dr. Blumenau, era um protestante conservador. Ele temia a disseminação de ideias não religiosas e liberais, principalmente por parte de Fritz. Pensamentos humanistas poderiam causar desafetos e revoltas na colônia, até entáo pacífica. Ele comentou em carta ao tio dos Müller, Hermann Trommsdorff, que não concordava com as ideias de Fritz sobre religião e lamentava que ele, com todo o seu conhecimento e energia, tivesse escolhido viver entre os colonos no meio do mato (WEST, 2003, p. 96). Vale salientar a satisfação e felicidade de Fritz: ele não tinha planos de voltar à Alemanha, o que de fato nunca fez, nem mesmo para visitar familiares.

Quando o presidente da Província de Santa Catarina, João José Coutinho (1809-1870), decidiu reabrir em 1856 a única escola mantida na capital, Nossa Senhora do Desterro (atual 
Florianópolis), anteriormente dirigida por padres jesuítas ${ }^{16}$, o Dr. Blumenau logo recomendou Müller ao cargo de professor, para que este fosse "aproveitado" em um melhor ofício e, de forma concomitante, ficasse afastado dos colonos. Ele foi imediatamente aceito para o cargo; porém, a função de professor lhe causou tristeza, como escreve aos irmãos residentes na Alemanha, visto que as suas primeiras plantaçôes de bananas, gengibre, abacaxi e outras frutas tropicais estavam sendo colhidas neste período. Todavia, como ele mesmo escreve, decide abandonar todo o seu trabalho agrícola pela oportunidade de se dedicar às atividades científicas, principalmente aquelas com animais marinhos, já que iria residir no litoral catarinense.

Müller permaneceu em Desterro (Figura 6) com a família por 11 anos (1856-1867), residindo na Praia de Fora (hoje aterrada, atual Avenida Beira-mar Norte). Este período foi muito importante, principalmente pelo cargo de professor ter garantido estabilidade financeira e tempo livre para ele se dedicar aos estudos no litoral, o que o levou a retomar suas pesquisas com crustáceos. Müller já tinha familiaridade com o tema, devido às pesquisas que realizou no período de estudos em Greifswald, cidade localizada na costa do Mar Báltico ${ }^{17}$.

Como professor, iniciou suas atividades no Liceu em fevereiro de 1857, ministrando três horas de aulas por dia a dois estudantes. Neste período, se familiarizou com o idioma, visto que as aulas eram em português. No segundo ano de atividade, ministrou

16 Em 1852 a escola foi fechada devido à epidemia de febre amarela que assolou a cidade de Desterro, culminando na morte de sete padres professores (SCHMIDT, 2009).

17 No verão de 1848, Müller publica um artigo sobre novas espécies do gênero Tanais, um crustáceo anfípode classificado àquela época como isópode. Ele descreveu em detalhes as espécies e comentou que não tinha publicado novos nomes porque os estágios imaturos de muitos ainda não eram conhecidos (WEST, 2016, p. 30). 
aula para quatro estudantes e no terceiro ano, para 22, com quatro horas de aula diárias. Apesar da deficiência de material para o ensino, como comentou em correspondência ao irmão Hermann, ele acrescentou que a Língua Portuguesa era muito útil para o ensino de matemática, pois as construçóes verbais no particípio e no infinitivo permitiam expressar com exatidão as fórmulas e teorias, diferente da Língua Alemã. (WEST, 2003, p. 102).

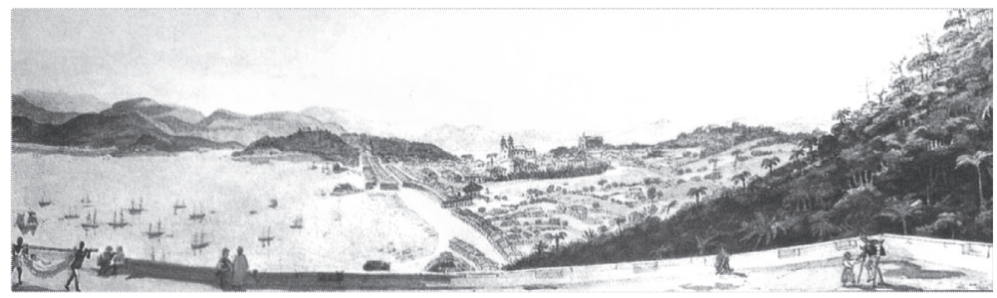

Figura 6 - Nossa senhora do Desterro no século XIX. Aquarela de Jean Baptiste Debret (1768-1848): Vista da vila de Desterro, a partir do hospital, 1827. Fonte: Makowiecky (2010).

Quanto à educação escolar, o autor também fez um relato, uma descrição histórica sobre a educação no século XIX em Santa Catarina. Ele descreve que a escola é diferente do conceito de ginásio alemão, pois nas escolas alemães não havia aulas fixas e nem um currículo padronizado, proporcionando a cada estudante se inscrever em qualquer classe que desejasse. Desse modo, alguns começavam a estudar latim; enquanto outros, francês ou matemática (WEST, 2003, p. 104).

Müller se dedicou aos estudos científicos e reiniciou suas publicaçóes, interrompidas em 1852, período da emigração. Os primeiros trabalhos no Brasil concentraram-se em descriçóes de espécies de diversos filos encontradas no litoral de Desterro, como os poríferos (esponjas), cnidários (águas-vivas e os corais) e crustáceos (caranguejos e camarôes). Seu primeiro trabalho 
enviado do Brasil para a Alemanha foi encaminhado, em 1856, ao amigo Max Schultze (1825-1874), que ficou responsável pela publicação. Neste texto, Müller fez uma comparação sobre as planárias terrestres, comparando-as com as espécies marinhas e as dulcícolas. Foi publicado na Revista Halle no mesmo ano, sob o título: Beiträge zur kentnnis der landplanarien. (Contribuiçóes ao conhecimento das planárias terrestres).

$\mathrm{O}$ amigo Schultze enviou neste período um microscópio para Müller realizar seus trabalhos. E, em 1861, remeteu ao amigo a edição alemá do livro de Charles Darwin (1809-1882), publicado em 1859 na Inglaterra, On the Origin of Species by means of natural selection or the preservation of favoured races in the struggle for life (Sobre a Origem das Espécies por meio da seleção natural ou a preservação de raças favorecidas na luta pela vida $)^{18}$. O "grande livro das espécies", como Darwin se referia à sua obra, começou a ser escrito em abril de 1856, porém os dados e muitas das observaçóes remetem ao ano de 1831, quando ele embarcou no HMS Beagle, na condição de naturalista e companheiro de viagem do capitão Robert FitzRoy. Ao embarcar, Darwin ainda acreditava na estabilidade das espécies. Porém, em 1835, no arquipélago de Galápagos, este conceito começou a ser mudado, conforme apontado em seu diário (MAYR, 2006). Darwin, todavia, era muito cauteloso em expressar suas opinióes sobre este assunto ${ }^{19}$. Mas, em 1858, Alfred Russel Wallace (1823-1913) enviou a ele seu ensaio para apreciação,

\footnotetext{
18 Neste trabalho, o livro será tratado apenas por Origin.

19 Alguns historiadores (como David Kohn) atribuem esta cautela de Darwin por medo da represália que sofreria pela sociedade científica inglesa, conservadora e protestante. Outros (como Dr. John van Wyhe) atribuem ao fato de Darwin buscar coletar mais materiais e evidências antes da publicação que viessem a corroborar com suas teorias, como por exemplo, o problema da especiação (PAPAVERO, LLORENTE-BOUSQUETS, 1994, p. 89).
} 
no qual havia chegado independentemente à mesma teoria da evolução por origem comum através da seleção natural. Após a leitura do trabalho, por pressão e sugestão dos amigos Thomas Huxley (1825-1895), Charles Lyell (1797-1875) e Joseph Dalton Hooker (1817-1911), o trabalho de Darwin foi apresentado junto ao de Wallace em uma publicação simultânea na Sociedade Linneana de Londres, presidida por Thomas Bell, no dia 01 de julho de 1858. A pesquisa de Darwin foi lida pelo secretário da Sociedade, pois Darwin não compareceu ao evento devido aos problemas de saúde em sua família ${ }^{20}$ (Figura 7).

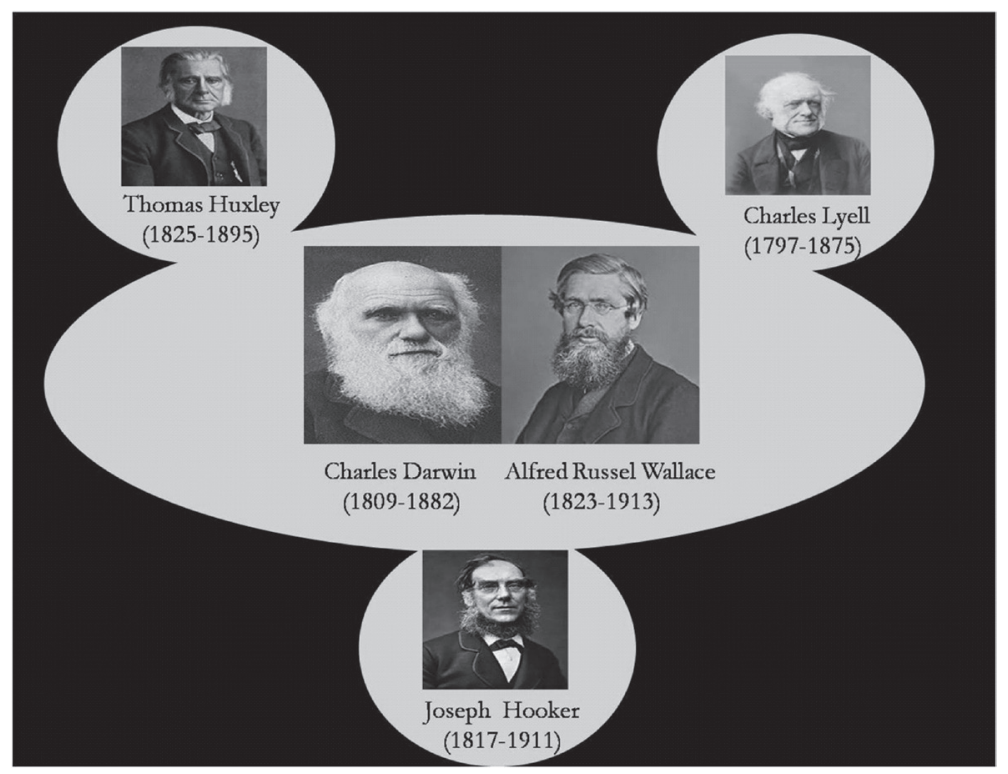

Figura 7 - Personagens importantes para a apresentação dos trabalhos de Darwin e Wallace em 1858. Fonte: Figura da autora.

\footnotetext{
20 Sua filha mais velha, Henrietta Emma, estava com difteria; seu filho Charles Walring Darwin, de um ano e meio, manifestou a febre escarlatina, o que o levou a óbito (HORTA, 2003).
} 
Charles Lyell era um importante geólogo da época e um dos primeiros defensores de Darwin, apesar de nunca ter admitido a seleção natural como mecanismo evolutivo. Thomas Huxley ficou conhecido posteriormente como o "buldogue de Darwin", dado seu posicionamento muitas vezes "feroz", em defender a teoria do amigo. Joseph Hooker, naturalista e botânico, também defensor de Darwin, acabou presidindo a Royal Society, a partir de 1873. Wallace enviou seu manuscrito a Darwin depois de seus estudos realizados na Indonésia.

Ao ler a obra de Darwin, Müller demonstrou grande interesse pelas teorias ali expostas, resultando em uma transformação no rumo de todas as suas publicaçôes posteriores. Após a leitura do exemplar, no dia 30 de outubro de 1861, ele escreveu aos seus familiares: "O livro de Darwin sobre a origem das espécies nos reinos animal e vegetal tem me dado, e ainda me dá, muito o que pensar" (WEST, 2003, p. 116).

E de tanto pensar nas teorias expostas em Origin, ele escreveu ao amigo Schultze em 1862, sobre a ideia acerca de um experimento:

Eu tinha em mente publicar algumas observaçôes gerais a favor da teoria da seleção natural de Darwin, mas desisti da ideia. A melhor prova da teoria será poder aplicá-la sem restrição a circunstâncias muito específicas e trazer clareza em meio a esse caos aparente. Espero que eu possa, assim, aplicá-la ao desenvolvimento dos crustáceos; e assim beneficiar a teoria mais do que pelas deduçóes usuais, as quais, afinal, aqueles que já aderiram a este ponto de vista já tenham acordado. Esta esperança tem me induzido a me dedicar exclusivamente a essa classe de animais (WEST, 2003, p. 117).

E para o irmão Hermann, também neste mesmo ano: 
Eu tenho quase que exclusivamente, no verão passado, me ocupado com os crustáceos, especialmente com o desenvolvimento de camarão, que lança uma luz inteiramente nova sobre as relaçóes de crustáceos e em toda a morfologia dos artrópodes, que eu espero que forneça evidências importantes a favor da teoria de Darwin sobre a origem das espécies animais e vegetais (WEST, 2003, p. 117).

Observa-se como Müller se propôs a dialogar com as teorias de Darwin num contexto histórico que ele analisa como de "caos aparente", denotando que havia um embate em torno dessas novas concepçóes propostas por Darwin. Portanto, escolheu contribuir com um estudo e um discurso mais especializado, algo característico de um cientista moderno. Um exemplo importante da transição, ocorrida no final do século XIX, de uma postura antiga do que era a função de um naturalista viajante, que muitas vezes se resumia a coletar exemplares para serem analisados pelos chamados "cientistas de gabinete" (KURY, 2001). Dessa forma, ao analisar-se a obra de Müller como naturalista viajante e como cientista moderno, observam-se as características do pensamento e da prática de pesquisa que até hoje marcam a consolidação da Biologia como área de conhecimento da ciência moderna ${ }^{21}$. Sua dedicação aos estudos dos crustáceos do litoral catarinense culminou na publicação de seu único livro, em 1864, na Alemanha, sob o título de Für Darwin (Para Darwin) (Figura 8). O livro foi revisado pelo amigo Schultze.

\footnotetext{
21 Para um melhor entendimento a respeito da constituição da ciência moderna, sugere-se uma consulta a Beltran (2014, p. 77-100).
} 


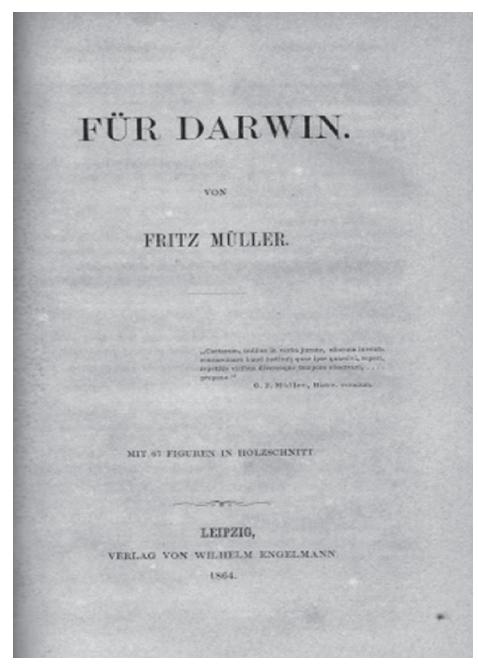

Figura 8 - Página de rosto da primeira edição alemã do livro Für Darwin, 1864. Fonte: Imagem gentilmente cedida da biblioteca particular do Dr. Luiz Roberto Fontes.

Em Für Darwin ${ }^{22}$, Müller analisou minuciosamente os dois grupos principais de crustáceos classificados até então, os inferiores e os superiores. A análise consistiu em observar o seu desenvolvimento larval e a morfologia de sua estrutura. Além disso, o cientista sugeriu novos princípios de classificação e, assim, dialogou com a Teoria da Seleção Natural, de Darwin. Porém, na época da pesquisa e da publicação do livro, havia um consenso entre os zoólogos e os "sacerdotes de uma ciência absoluta" - termo crítico utilizado por Müller para alfinetar os

22 Para maiores informaçóes, sugere-se uma consulta à tradução de Luiz Roberto Fontes e Stefano Hagen de 2009, realizada a partir do original em alemão e que contém a atualizaçáo taxonômica dos crustáceos estudados, bem como as correçóes e acréscimos da edição inglesa de 1869. MÜLLER, F. Para Darwin. [1864]. Florianópolis, UFSC, 2009, 280p. 
pesquisadores contrários as leis naturais já postuladas - de que os crustáceos apresentavam desenvolvimento indireto com fase larval. Era consenso entre os estudiosos os crustáceos superiores possuírem uma fase larval mais simples, denominada de náuplio. Em suas pesquisas, Müller descobriu entre os dois grupos uma fase evolutiva comum. Desta forma, dentro de um grupo, aparentemente táo diversificado, haveria um ancestral comum a todos os indivíduos, conforme sugeria a Teoria de Darwin. A partir desse estudo, Müller também sugeriu que todos os crustáceos, passando por formas larvais mais simples, carregavam a história de seus ancestrais na fase embrionária. Tal conceito foi posteriormente atribuído na historiografia a Ernst Haeckel. No entanto, trata-se de um "empréstimo" do conceito de Müller" de que a ontogenia (desenvolvimento individual do organismo) recapitula a filogenia (desenvolvimento evolutivo do grupo ancestral).

Além do desenvolvimento embrionário e larval, outro assunto explorado pelo naturalista em seu livro são as descriçôes sobre o dimorfismo no gênero de isópode Tanais (Latreille, 1831). Ele observou que, dentre os machos, alguns apresentavam grandes pinças, enquanto outros nâo possuíam a estrutura desenvolvida, porém apresentavam como característica distintiva antenas com muitos filamentos olfativos (MÜLLER, 2009, p. 46).

A opinião científica vigente à época era explicar tais variedades encontradas na natureza como parte de um plano maior de criação divina ${ }^{23}$, ou seja, as diferenças existentes dentro de uma mesma espécie existiam porque Deus havia planejado. Com o advento das teorias evolucionistas entre o final do século XVIII

\footnotetext{
23 Após a revolução científica do século XVIII, muitos pesquisadores não abandonaram a sua fé cristã e ainda utilizavam o ponto de vista religioso para explicar os fenômenos científicos (MAYR, 2008, p. 51).
} 
e início do XIX muitos pesquisadores começaram a questionar tal plano. Porém, não havia uma teoria que explicasse os pormenores existentes na natureza. Então, a solução era buscar conciliar a ciência e a religião, atribuindo as "causas aparentemente sem solução" como algo divino. O paradigma foi substituído de forma gradual com o lançamento de Origin. Assunto para o próximo capítulo.

Já se viu como Müller rompeu com os dogmas religiosos bem antes da leitura do livro de Darwin, não aceitando a influência "divina" no mundo científico. Para ele os "mistérios" da natureza poderiam ser elucidados a partir do momento em que o pesquisador não aceitasse respostas prontas ou conformistas. Nesse sentido, a teoria de Darwin e sua aplicação sobre tais casos antes não explicáveis ofereciam sentido e significado para ele (MÜLLER, 2009, p. 48). De fato, Müller utilizou as teorias do naturalista inglês para explicar o dimorfismo existente nos machos isópodes: para ele, os farejadores (dotados de antenas com os filamentos olfativos) e os agarradores (com pinças maiores), possuíam uma origem comum e se diferenciavam a partir da seleção natural, pois ambos competiam para garantir sua sobrevivência.

Em Für Darwin, Müller buscou dialogar com as teorias propostas por Darwin às diversas situações encontradas na natureza. Um exemplo foram suas explicaçóes baseadas na descendência comum para explicar a presença de cavidade branquial em caranguejos terrestres e também na variabilidade de posiçáo do coração em ordens próximas de crustáceos.

Müller, no entanto, tratou sua contribuição no contexto da criação e validação do conjunto das teorias da evolução apresentadas por Darwin, de forma bastante modesta, conforme ele comentou no final de seu livro: "Sob a mão de Darwin, porque nada mais tenho a fazer além de colocar as pedras da construção na posição que a sua teoria lhes indica. 'Quando os reis 
constroem, os carroceiros têm que trabalhar'” (MÜLLER, 2009, p. 71).

O próprio comentário de Müller a respeito de seu trabalho com Darwin e o título dado ao seu livro são bastante reveladores da permanência da velha hierarquia entre os "cientistas de gabinete"- estes viviam nos países centrais da Europa, considerados sede e berço do conhecimento científico moderno - e os "naturalistas viajantes", residentes nas regióes mais afastadas do que era considerado o epicentro dos grandes debates da ciência moderna, que surgiram no século XIX e se estenderiam ao longo do século XX. Também convém ressaltar que após o lançamento de Origin muitos pesquisadores buscaram "adequar" suas pesquisas às novas teorias, a exemplo de Henry Walter Bates (1825-1892), que utilizou a Teoria da Seleção Natural para explicar sua proposição de mimetismo em duas espécies de borboletas encontradas na região amazônica, no ano de 1862 .

Sem preâmbulos, Für Darwin foi muito bem recebido no meio científico alemão (WEST, 2003, p. 118-119) e também por Darwin, que, após ter contato com o livro, escreveu a Müller para elogiar o excelente trabalho por este realizado. Além disso, também se responsabilizou pela publicação e pelo custeio da edição inglesa.

A edição inglesa de Für Darwin foi publicada cinco anos após a alemá, sob o título de Facts and arguments for Darwin (Fatos e argumentos a favor de Darwin) (Figura 9). O nome foi sugerido pelo geólogo Charles Lyell (1797-1875).

Nota-se na capa da primeira edição inglesa o nome de Darwin em fonte maior, contrastando com o nome do próprio autor. Este fato foi visualizado por Darwin na prova de impressão de publicação, e posteriormente ele pediu aos editores a correção, porém não foi atendido. 


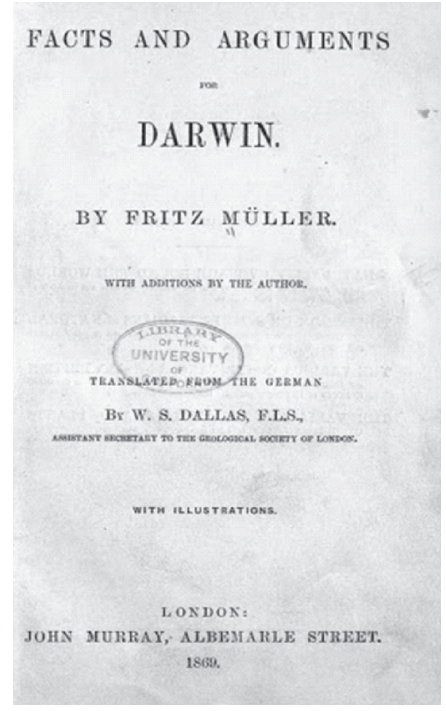

Figura 9 - Página de rosto da primeira ediçáo inglesa de Für Darwin, de 1869, patrocinada por Darwin. Fonte: Internet Archives (2016).

Müller trocou correspondências com Darwin por 17 anos, no período de 1865 a 1882 . A título de curiosidade vale lembrar que a primeira carta foi escrita por Darwin e enviada ao naturalista alemão após a leitura de seu livro. Se Müller tivesse escrito a Darwin depois da leitura de Origin, ocorrida no ano de 1861, com certeza haveria mais epístolas disponíveis.

Zillig (1997) traduziu as cartas entre os dois naturalistas para o português. Durante o processo de tradução, ele encontrou 39 cartas de Darwin a Müller e 34 de Müller a Darwin. Dentre os assuntos discutidos pelos naturalistas, nota-se que Darwin encomendava ao amigo residente no Brasil muitas pesquisas sobre assuntos impossíveis de se pesquisar na Europa. Exemplos são os tucanos, as orquídeas e as bromélias. A influência dos estudos de Müller sobre Darwin ainda é um assunto que carece de mais 
pesquisas na historiografia. Porém, nas ediçóes posteriores de Origin corrigidas pelo autor, o nome de Müller é citado mais de 17 vezes (ZILLIG, 1997, p. 2).

West (2016, p. 8) indica que o possível "rival” de Müller na amizade com Darwin era J. D. Hooker. Darwin e Hooker trocaram em torno de 400 cartas ao longo de 40 anos. As correspondências eram principalmente sobre assuntos botânicos. Darwin e Müller, por outro lado, discutiram diversas observaçóes e ideias que ambos utilizariam em suas publicaçóes futuras. Darwin ainda dizia a Müller que suas opiniōes eram as que ele mais valorizava. De fato, até mesmo o filho de Darwin, Francis, escreveu em 1887: "Minha impressão é que de todos os seus amigos invisíveis, Fritz Müller era o único com quem teve consideração mais forte”.

A amizade e a troca de informaçôes científicas fizeram com que Darwin apelidasse Müller de "Príncipe dos observadores" (CASTRO, 2007, p. 86) devido às observaçóes minuciosas da natureza realizadas pelo naturalista. Aqui é importante ressaltar que, diferentemente dos naturalistas europeus, que possuíam à disposição os mais recentes equipamentos técnicos para suas pesquisas, todas as investigaçôes de Müller feitas em Santa Catarina foram executadas com pouco equipamento. $\mathrm{O}$ equipamento mais luxuoso e tecnológico utilizando por Müller foi um microscópio simples enviado pelo amigo Schultze, da Alemanha.

Müller foi um pesquisador original que não se submeteu ao academicismo e preferiu viver em uma terra longínqua, pesquisando e estabelecendo fatos que outros não puderam observar. Ao contrário de Darwin, que náo realizava os próprios experimentos, mas se valia de dados enviados por outros pesquisadores, Müller era um observador minucioso. Ele realizou seus próprios experimentos e escreveu sobre todas as estruturas detalhadamente, conforme seus recursos possibilitavam. Nesse sentido, como 
já apontado anteriormente, suas pesquisas foram originais para o contexto científico de sua época e possuem desdobramentos até a atualidade, sendo considerado ainda o maior pesquisador do bioma "Mata Atlântica" de Santa Catarina (FONTES, 2007).

Em Desterro, atuou como professor do Liceu Provincial até 1867 . Em 1859, o presidente da província, João José Coutinho, foi substituído pelo gaúcho Francisco Carlos de Araújo Brusque (1822-1886), com quem Müller não simpatizava. Brusque entregou o Liceu novamente aos jesuítas, que o rebatizaram como Colégio da Santíssima Trindade. Müller, na condição de concursado, não podia ser demitido, mas os jesuítas não queriam mantê-lo como professor. A solução encontrada foi desvincular os professores estrangeiros do quadro de funcionários. Após diversos atritos com o diretor, Padre Paiva, Müller se dirigiu, em 1867, à Assembleia Provincial sugerindo que fosse enviado novamente à sua colônia, porém como pesquisador de flora e fauna locais. O pedido foi aprovado e Müller regressou a Blumenau em 1867, vivendo na cidade até sua morte, em 1897.

\subsection{A educação das meninas}

As escolas do Brasil Império eram organizadas com base em leis editadas em 1827 e, a partir de 1834, a instrução primária e secundária passou a ser legislada sob a responsabilidade de cada província (SCHMIDT, 2012). Segundo Schmidt, data de 1835 a primeira lei provincial de instrução primária em Santa Catarina, e nela estão reproduzidos alguns artigos da Lei Imperial de 15 de outubro de 1827.

O relatório anual de 1859, transmitido ao Presidente da Província de Santa Catarina, João José Coutinho, relata o quanto 
era precário o sistema de ensino: dos 1.207 alunos matriculados em escolas masculinas, apenas 37 realizaram o exame e foram aprovados; enquanto que das 422 meninas matriculadas em escolas femininas, 13 realizaram o exame e apenas nove foram aprovadas (SCHMIDT, 2012). Esse relatório também informa que as instalações físicas das escolas não eram adequadas e, além disso, faltavam professores qualificados.

Desde o estabelecimento da colônia, o Dr. Blumenau também buscou estabelecer escolas, e obteve um professor em 1850, graças ao governo imperial. O próprio irmão de Müller, August, manteve uma escola por muitos anos na colônia. Já no final de 1860, a colônia possuía 20 escolas particulares. Porém era difícil encontrar bons professores, porque os colonos nem sempre possuíam recursos para pagar.

Müller e Karoline tiveram dez filhos: nove meninas e um menino. A primeira filha, Louise, veio à luz enquanto o casal ainda residia na Alemanha e o único menino, nascido no Brasil, sobreviveu apenas poucas horas após o nascimento. As demais filhas nasceram já em território brasileiro. Em 1865, nasceu Martha, porém esta viveu apenas quatro meses. As outras filhas do casal foram: Johanna, Rosa, Agnes, Emma, Thusnelda, Selma e Linda.

As meninas foram educadas pelo pai durante a residência em Desterro. Müller proporcionou a elas uma educação de qualidade e estimulou o uso do alemão como primeira língua, diferentemente de outros alemães residentes no Brasil.

Devido às duas filhas mais velhas (Johanna e Rosa) gostarem de ler e já saberem as histórias infantis dos livros memorizadas, Müller confessou à irmã Rosine, em 1858:

Desejaria que um dia pudéssemos ter aqui alguém como Hey, que iria escrever poemas para os nossos filhos, os quais 
os belos contos europeus do corvo, do boneco de neve, e os restantes são incompreensíveis; enquanto que os nossos beija-flores, papagaios, macacos, tucanos, gambás (ratos marsupiais), onças, etc., forneceriam material abundante. Alguém aqui vai ter que escrever um livro de leitura para os seus próprios (WEST, 2003, p. 107).

As fábulas de Wilhelm Hey (1789-1854) eram ambientadas na Alemanha e descreviam um universo totalmente diferente, com outra vegetação e outros animais não encontrados no Brasil. Müller, então, empenhou-se em elaborar pequenas histórias com personagens tipicamente brasileiros, para que a leitura às suas filhas, além de prazerosa, estivesse inserida na realidade local.

Em 1859, Müller escreveu e ilustrou 12 poemas com o intuito de educar suas filhas. Além de encantar com sua simplicidade poética, os poemas buscavam interpretar as relações ecológicas na natureza, revelando cenas ou fatos cotidianos, promovendo ensinamentos e transmitindo valores morais, a partir de cenários e personagens da fauna e flora de nosso país.

A sensibilidade de Müller para construir a sua interpretação da natureza, bem como traduzi-la na forma de poemas, também esteve presente em suas filhas: Rosa era uma exímia desenhista, ao passo que Johanna, também conhecida como Anna, tornou-se escritora quando adulta.

Segundo Sousa (2012), as histórias de Johanna, conhecida como Anna Brockes (posto que adotou o sobrenome do marido, August Heinrich Brockes, após o casamento em 1879), possuíam um caráter regional, voltando-se para a vida no campo. Assim como as narrativas do pai, as de Anna eram didáticas, e possivelmente foram escritas como ferramenta educativa para seus filhos e netos. De acordo com informaçôes obtidas por Sousa (2012), 
Anna era uma mulher culta e sofisticada, chegando a possuir uma fábrica de chapéus em Blumenau.

Apesar de Müller adotar um posicionamento liberal, tais pensamentos não eram encorajados na educação de suas filhas, pois ele acreditava que as crianças não deveriam ser estimuladas às doutrinas quando pequenas, mas sim esperar o momento oportuno, até elas crescerem e poderem decidir por si próprias os caminhos a serem percorridos, conforme relatou em carta à sua irmã Rosine, em 1858.

\subsection{Os delírios, as bromélias, a solidáo}

Nos últimos anos de sua vida, Müller envolveu-se demasiadamente com a política em Blumenau, chegando até mesmo a ser preso em 1893, no auge da Revolução Federalista ${ }^{24}$.

Longe de seu cargo como naturalista viajante (exonerado em 1892), com profunda tristeza e depressão que o assolou desde 1879 , em razão do suicídio de sua filha Rosa em Berlim, Müller também perdeu seu amigo Darwin (1882), seu irmão Hermann (1882) e sua esposa Karoline (1893).

Sem os amigos e alguns familiares já falecidos, com as filhas casadas e muitas partindo de Blumenau, Müller encontrou companhia em seu neto pequeno, Fritz. O jovem neto acompanhava o avô nas excursôes floresta adentro.

\footnotetext{
${ }^{24}$ A Revolução Federalista ocorreu entre 1893 e 1895, inicialmente no Rio Grande do Sul e posteriormente atingindo Paraná e Santa Catarina. As principais causas foram a insatisfação dos federalistas com o domínio político de Júlio de Castilhos (presidente do RS), do Partido Republicano Rio-grandense e a disputa política entre dois grupos políticos gaúchos: os chimangos (pica-paus) e os maragatos (federalistas).
} 
Müller recebeu em 1892, por ocasião de seu $70^{\circ}$ aniversário, inúmeras mensagens de amigos e sociedades científicas. Entre os presentes, constam um álbum de fotografias de colegas cientistas alemães, abertura de conta de um livreiro em Berlim, homenagens em livros sobre crustáceos de pesquisadores franceses, concessão de títulos como membro honorário em diversas sociedades científicas etc. Era uma figura reconhecida internacionalmente, mas no Brasil náo recebeu merecidas honras, como aponta West (2003, p. 275).

Em 1897, decidiu vender sua casa e seus terrenos no Vale do Itajaí e partilhou seus bens entre as filhas. Já doente, passou os últimos dias de vida na casa de Anna.

Müller morreu de uma inflamação sistêmica no dia 21 de maio de 1897, e foi sepultado no cemitério protestante da cidade de Blumenau. Seu irmão August, que o visitou três dias antes do falecimento, narrou ao primo Alfred Möller, seu futuro biógrafo, que Müller, apesar de lúcido e sem febre, descartou qualquer esperança de recuperação.

Em 1899, o Museu Nacional publicou nos Archivos seu necrológio:

No dia 21 de maio de 1897, em Blumenau, Estado de Santa Catarina, Brasil, a morte cerrou para sempre os olhos de um anciáo venerando, cuja existência foi toda ela voltada em benefício da ciência e ao mesmo tempo um modelo de honradez e um exemplo de quanto pode conseguir a energia da vontade quando visa fins elevados. Com o cérebro afeiçoado e iluminado para as elucubraçóes científicas, ele atravessou uma boa parte de sua existência no meio da natureza tropical, nas margens verdejantes dos regatos, na borda dos lagos quietos e adormecidos (Archivos do Museu Nacional, 1899, p. XIII). 
Walter Blandford, secretário da Sociedade Entomológica de Londres, escreveu à revista Nature sobre as contribuiçôes de Müller:

Se o seu nome não está associado a nenhum grande avanço no pensamento, exceto em uma ou duas questóes especiais relacionadas com a seleção natural, é porque ele encontrou sua fé intelectual na teoria que ele pôs-se a desenvolver e fortalecer. Ele estava contente, de fato, por ajudar na construção da estrutura da qual outro era arquiteto, e nessa tarefa seus serviços foram muito grandes. Pode-se questionar se qualquer outro naturalista, senão o próprio Darwin, deu ao mundo tão grande e original gama de observaçóes nas quais a seleção natural tem sido tão fortemente apoiada (WEST, 2003, p. 292).

Muitos necrológios se sucederam a este, em que o conteúdo é geralmente vinculado ao nome de Darwin. Müller não publicou um livro de registro sobre sua vida em Santa Catarina, como Darwin muitas vezes o aconselhou a fazer. Faltava-lhe, como diria ao amigo em cartas, o frescor da juventude da filha Rosa para desenhar e compilar seus materiais.

Castro (2007, p. 142) nos conta que Müller, em seus últimos dias de vida, já doente e acamado, delirava falando sobre bromélias:

Os parentes que o assistiram nos últimos momentos puderam reconstituir, através de frases soltas, o seu delírio. Era um desfilar de espécies sem conta de bromélias, umas familiares - suas "velhas conhecidas", como dizia -, outras nunca vistas (CASTRO, 2007, p. 145).

Ao consultar as publicações de Müller, percebe-se uma inclinação para os estudos de bromélias, pouco antes de sua morte. Afirmando, sem questionamentos, a veracidade de seus delírios e a agonia daquele que sabia que não conseguiria prosseguir com seus estudos. 
Quanto mais alta a construção, tanto mais ampla, em fatos bem reconhecidos, deve ser a base que a sustenta.

Fritz Müller 